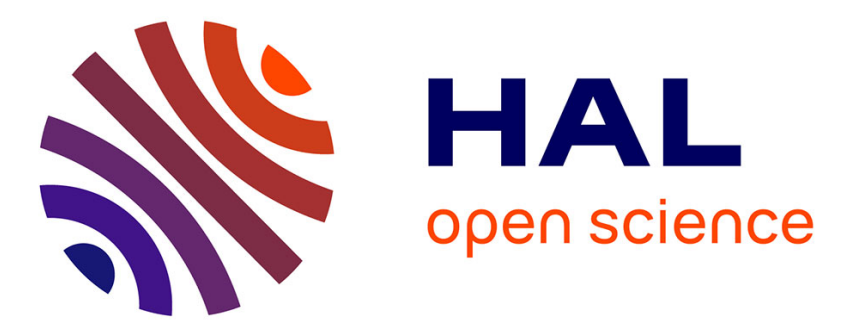

\title{
A Linking Test that establishes if groundwater recharge can be determined by optimising vegetation parameters against soil moisture
}

Joseph Alexander Paul Pollacco, Isabelle Braud, Rafaël Angulo-Jaramillo, Bernard Saugier

\section{To cite this version:}

Joseph Alexander Paul Pollacco, Isabelle Braud, Rafaël Angulo-Jaramillo, Bernard Saugier. A Linking Test that establishes if groundwater recharge can be determined by optimising vegetation parameters against soil moisture. Annals of Forest Science, 2008, 65 (7), pp.1. hal-00883419

\section{HAL Id: hal-00883419 https://hal.science/hal-00883419}

Submitted on 1 Jan 2008

HAL is a multi-disciplinary open access archive for the deposit and dissemination of scientific research documents, whether they are published or not. The documents may come from teaching and research institutions in France or abroad, or from public or private research centers.
L'archive ouverte pluridisciplinaire HAL, est destinée au dépôt et à la diffusion de documents scientifiques de niveau recherche, publiés ou non, émanant des établissements d'enseignement et de recherche français ou étrangers, des laboratoires publics ou privés. 


\title{
A Linking Test that establishes if groundwater recharge can be determined by optimising vegetation parameters against soil moisture*
}

\author{
Joseph Alexander Paul Pollacco ${ }^{1 * *}$, Isabelle BRAUD ${ }^{2}$, Rafael ANGULO-JARAMILLO ${ }^{1,3}$, \\ Bernard SAUGIER ${ }^{4}$

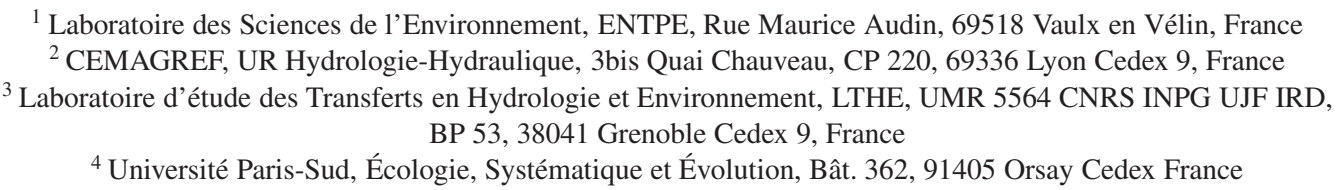

(Received 10 January 2008; accepted 4 June 2008)

Keywords:

Linking Test /

inverse modelling /

soil moisture /

vegetation parameters /

groundwater recharge

Mots-clés :

test de Liaison /

model inverse /

humidité du sol /

paramètres de végétation /

recharge

\begin{abstract}
- The impact of afforestation/deforestation on groundwater recharge can be predicted by using onedimensional soil-vegetation water flow models based on Richards' equation. However simulations depend upon parameters that are not easily measurable.

- Pollacco et al. (2008) showed that the hydraulic parameters can be determined, if the vegetation parameters are known, by fitting simulated time series of soil moisture profiles to those measured in situ. This paper presents a case study to determine if the interception and crop factor parameters can tentatively be calibrated by fitting soil moisture profiles. Synthetic data were used and the other vegetation parameters and the soil hydraulic parameters were assumed to be known.

- We applied and improved the Linking Test developed by Pollacco et al. (2008) to look for links between the parameters that need to be calibrated, and thus to investigate whether inverse modelling is feasible, which depends on the accuracy of the calibration data.

- The Linking Test established that interception and evapotranspiration parameters are linked and, therefore, uncertainty on interception compensates for uncertainty on evapotranspiration. Thus in spite of a good match between observed and simulated soil moisture data, inverse modelling is unfeasible. This is true even if the interception or the crop factor parameters are known, because an error on interception or evapotranspiration will be compensated by an error on groundwater recharge without affecting soil moisture.

- This paper recommends that vegetation parameters should not be calibrated by optimisation against soil moisture data.
\end{abstract}

Résumé - Un Test de Liaison qui établit si la recharge des eaux souterraines peut être quantifiée en optimisant les paramètres de végétation grâce aux profils d'humidité du sol.

- L'impact de la déforestation/reforestation, sur la recharge des eaux souterraines, peut être quantifié en employant les modèles unidimensionnels d'écoulement dans le continuum sol-plante-atmosphère. Ces modèles sont fondés sur la solution de l'équation de Richards. Cependant, quel que soit le modèle, les simulations dépendent de paramètres qui sont difficilement mesurables.

- Pollacco et al. (2008) ont montré comment les paramètres hydrodynamiques du sol peuvent être déterminés, lorsque ceux de la végétation sont supposés connus, en ajustant une série chronologique simulée de profils d'humidité du sol à des profils mesurés in situ. Cet article recherche, à travers une étude de cas, si les paramètres d'interception et le coefficient cultural peuvent être estimés à partir des profils d'humidité du sol. Des données synthétiques simulées sont employées dans l'estimation tout en supposant connus les autres paramètres de végétation et les paramètres hydrodynamiques du sol. - Le Test de Liaison développé par Pollacco et al. (2008) a été amélioré afin d'établir le lien existant entre les paramètres qui doivent être estimés, et de déterminer si la modélisation inverse est réalisable, ce qui dépend de la précision des données d'étalonnage.

\footnotetext{
* For Nomenclature, see page 13.

**Corresponding author: pollacco.water@gmail.com
} 
- Le Test de Liaison a permis d'établir le degré de liaison entre les paramètres d'interception et d'évapotranspiration, et en conséquence d'estimer de combien l'incertitude sur l'interception compense celle sur l'évapotranspiration. Ainsi, malgré une bonne correspondance entre les données d'humidité de sol observées et simulées, la modélisation inverse n'est pas faisable. Ceci reste vrai même lorsque les paramètres d'interception et le coefficient cultural sont connus, car les erreurs sur l'interception ou l'évapotranspiration sont compensées par une erreur sur la recharge. Ces erreurs n'ont pas d'effet sur l'humidité du sol.

- Cet article suggère que les paramètres de végétation ne devraient pas être estimés par optimisation sur des données d'humidité du sol.

\section{INTRODUCTION}

White et al. (2000) modelled the consequence of changing climate on forest growth and concluded that forests between latitudes $30 \mathrm{~N}$ and $60 \mathrm{~N}$ will increase: more favourable temperatures, adequate rainfall and nitrogen deposition are enhancing forest growth. Afforestation is also increasing in industrialised countries because increases in crop yield allowed a decrease in crop area, liberating large surfaces for forests. The European Commission directives (EEC, 1992) encourage farmers to convert agricultural land into woodland, in exchange of payments, in order "to provide more benefits for society and the environment" (Forestry Commission, 1998). The UK Government's White Paper on Rural England (Her Majesty's Stationary Office, 1995) also proposes a doubling of woodland area by the year 2045.

Thus, there is a growing need to determine the impact of afforestation on groundwater recharge by using a reliable and cost-effective method (Cubera and Moreno, 2007). In most case studies, groundwater recharge (i.e. soil water flux below the root zone) and evapotranspiration were shown to be accurately estimated by using physically based distributed models with a sink term that solves the Richards' equation (e.g. Ball and Trudgill, 1995; Keese et al., 2005; Ross, 1990; Singh, 1995). Widely used models in this class include SHETRAN (Ewen et al., 2000), SWIM (Krysanova et al., 2005), HYDRUS (Simunek et al., 1998); WAVES (Zhang and Dawes, 1998); PEARL (Bouraoui, 2006) and SOIL-SiSPAT (Braud et al., 2005). A drawback of such physically based models is that they require a considerable number of hydraulic and vegetation parameters that need to be determined. Most of them are measured through a combination of costly and timeconsuming laboratory and field methods. An additional drawback arises because the measurements are performed on samples that poorly characterize field conditions. Consequently, when it is possible, it is preferable and less tedious to estimate these parameters indirectly in situ.

Groundwater recharge is rarely measured. Therefore, in a research project in lowland UK, Calder et al. (2002) attempted to model groundwater recharge under various vegetation types by optimising simultaneously the hydraulic and the vegetation parameters of a one-dimensional Richards' soil water flow model. In this site runoff was not observed (Calder et al., 2002). The parameters were optimised by solely matching observed and simulated time series of soil moisture $(\theta)$ profiles measured in situ. The soil water model used precipitation and potential evaporation as inputs. Calder et al. (2002) found an excellent fit between observed and simulated $\theta$ profiles and determined that the optimal winter crop factor ${ }^{1}(\beta)$ of oak was equal to 0.82. Nevertheless, we believe that the value of $\beta$ was over predicted. Bobay (1990), Nizinski and Saugier (1989) indirectly measured the crop factor of a chestnut coppice near Orsay and of an oak forest near Fontainebleau (50 km south of Paris), respectively. They found a much lower value of 0.3 for $\beta$ in winter, which is expected since the shedding of leaves by deciduous trees considerably reduces their water loss. Calder et al. (2002) also optimised the winter interception parameters and found that interception was equal to $18 \%$ of the annual rainfall. However, Nizinski and Saugier (1989) measured oak interception and found it to be equal to $25 \%$. Hence, it is suggested that Calder et al. (2002) over predict evapotranspiration and under predict interception. The question addressed in this paper is to determine the reasons why Calder et al. (2002) found such dissimilar results as compared to Nizinski and Saugier (1989).

The first step of this investigation has been answered by Pollacco et al. (2008). Pollacco et al. (2008) used a onedimensional Richards' soil water flow model in a temperate oak forest and, assuming vegetation parameters are known, tried to determine groundwater recharge by optimising the hydraulic parameters against time series of soil moisture profiles. They found that a unique groundwater recharge could be obtained but that the optimal hydraulic parameters were not unique. In the present case study we assume the hydraulic parameters are known and we want to know whether accurate groundwater recharge could be determined by optimising the vegetation parameters against $\theta$. The root water uptake parameters are assumed to be known, since Hupet et al. (2002; 2003), Musters et al.(2000), Musters and Bouten (1999; 2000) showed that the root water uptake parameters are not sensitive enough to be optimised against $\theta$. In this case study the vegetation parameters consists of 3 parameters: 2 interception parameters and 1 crop factor parameter. The simulations are performed in the summer period rather then in winter, since the sensitivity of the vegetation parameters in summer is considerably higher. If there is a discrepancy in winter there will likely be a discrepancy in summer.

To determine if the vegetation parameters can be optimised against $\theta$, we are questioning if the optimised vegetation $p a-$ rameters suffer from equifinality. This term has been defined by Beven (1993). Equifinality occurs when more than one

\footnotetext{
${ }^{1}$ Crop factor takes account of the different biophysical properties of the vegetation, which leads to a reduction in the evaporation rate of potential evaporation.
} 
set of parameters give similar values of an objective function (OF). It is important to identify the impact of the parameter sets suffering of equifinality on the water fluxes (recharge, interception and evapotranspiration). Pollacco et al. (2008) define several categories of parameters:

- Non-sensitive parameters: parameters whose values in the feasible parameter space, have little influence on OF, water fluxes and on the other optimal parameters. The nonsensitive parameters may be caused by the restrained range of the forcing data;

- Natural parameter sets: all parameters that are neither non-sensitive parameters nor linked parameters are considered to be natural parameter sets. There will always be sets of parameter causing equifinality due to inaccuracy in the data and in the model. A well-defined inverse problem would have at least the natural parameter sets restrained such that the response surface of the OF would have a well defined global minimum (depression).

- Sets of linked parameters: when parameters are linked, there is an infinite combination of sets of linked parameters that produces OF values close to that obtained with the optimum parameter sets (global optimum).

There are different categories of linked parameter sets that are classified by Pollacco et al. (2008) as:

- Sets of falsely linked parameters: all the water fluxes such as groundwater recharge, interception and evapotranspiration are influenced by the sets of falsely linked parameters. Therefore, the inverse modelling is not feasible. Sets of falsely linked parameters will be investigated in this case study.

- Sets of partially linked parameters: only one water flux such as groundwater recharge is not influenced by the sets of partially linked parameters, but others (i.e. evaporation and interception) are linked and therefore not unique. A Linking equation can be computed between the different sets of partially linked parameters.

- Sets of truly linked parameters: all the water fluxes are not influenced by sets of linked parameters. A Linking equation can be estimated between the different sets of truly linked parameters. Pollacco et al. (2008) established that when optimising the hydraulic parameters against $\theta$, the hydraulic parameters are found to be sets of truly linked parameters.

Many calibration methods do not provide a complete description of the model/data identification problem since they do not separate poorly identifiable parameters from parameters that are linked and are thus not able to provide complete information about the source of the problem (Pollacco, 2005; Pollacco, et al., 2008). Therefore, Pollacco et al. (2008) developed a simple but robust inverse method named the Linking Test that is able to differentiate between non-sensitive parameter sets, natural parameter sets and linked parameters. The Linking Test investigates whether the inverse modelling is feasible, by establishing whether the expected accuracy of the model output (recharge) can be attained by optimising the vegetation parameters against $\theta$. If the required accuracy of the recharge cannot be guaranteed, then the Linking Test offers methods of exploring the causes, and ascertains if further data can alleviate the non-uniqueness. In our case study the "true" vegetation parameter sets are known as we use synthetic data, where a reference simulation is generated using a prescribed set of vegetation parameters. For this case study, we used the soil-vegetation water transfer model (SOIL-SiSPAT) that was used to solve a number of hydrological problems (Braud, 2000; Braud et al., 1995; 2005).

\section{MATERIALS AND METHODS}

\subsection{Description of the Linking Test}

The Linking Test is applied to the flow model SOIL-SiSPAT to determine if different combinations of simulated vegetation parameters $\left(\right.$ PARAM $\left._{\text {sim }}\right)$, can produce simulated soil moisture profile $\left(\theta_{\text {sim }}\right)$ similar to a reference soil moisture profile $\left(\theta_{\text {ref }}\right)\left(\mathrm{cm}^{3} \mathrm{~cm}^{-3}\right)$ and simulated cumulative recharge given at a depth of $1.9 \mathrm{~m} Q_{\text {sim }}(\mathrm{mm})$, similar to a reference cumulative recharge $Q_{\text {ref }}(\mathrm{mm})$. The reference outputs are computed by introducing a known reference set of vegetation parameters $\left(\right.$ PARAM $\left._{r e f}\right)$ into SOIL-SiSPAT. In this case study, the reference set of vegetation parameters is for an oak forest. PARAM sim are generated by using an optimisation algorithm that reduces the value of an objective function $(O F)$, by matching daily reference time series of soil moisture $\theta_{\text {ref }}(z, t)$ for each soil layer with simulated time series of soil moisture $\theta_{\text {sim }}(z, t)$. The $O F$ used is computed as:

$$
O F=\sqrt{\frac{\sum_{j=0}^{N_{t}}\left\{\sum_{i=l}^{N_{z}}\left[\theta_{\text {ref }}\left(z_{i}, t_{j}\right)-\theta_{\text {sim }}\left(z_{i}, t_{j}\right)\right]^{2}\right\}}{N_{z} \cdot N_{t}}}
$$

where $N_{z}$ is the number of cells and $N_{t}$ is the number of days.

For a matter of simplicity, the terminology $P A R A M_{\text {sim }}$ includes also the corresponding values of $O F, Q_{\text {sim }}$, cumulative interception $(\Sigma I N T)[\mathrm{mm}]$ and cumulative evapotranspiration $(\Sigma E)[\mathrm{mm}]$. To determine the classes of the Linked parameter sets (sets of falsely linked parameters OR sets of partially linked parameters OR sets of truly linked parameters OR natural parameter sets) the modeller needs to provide two parameters $\Delta Q_{\max }$ and $O F_{\text {field }} . \Delta Q_{\max }(\%)$ is the maximum tolerated inaccuracy of estimating recharge by optimising the vegetation parameters against $\theta$. In our case study $\Delta Q_{\max }$ is chosen to be equal to $10 \%$. The error on $Q$ is computed by:

$$
\Delta \mathrm{Q}=100 \frac{\left|\mathrm{Q}_{\text {ref }}-\mathrm{Q}_{\text {sim }}\right|}{\mathrm{Q}_{\text {sim }}}
$$

$O F_{\text {field }}$ is the uncertainty in measuring $\theta$. In this paper, $O F_{\text {field }}=$ $0.02 \mathrm{~cm}^{3} \mathrm{~cm}^{-3}$. That was estimated by Sinclair and Williams (1979), Haverkamp et al. (1984) to be the accuracy of measurement reported for field experiments by using the neutron probe. $O F_{\text {field }}$ is then compared to $O F_{\triangle Q \max } . O F_{\triangle Q \max }$ is estimated by plotting $O F$ against $\Delta Q$ taken from $P A R A M_{\text {sim }}$. The maximum value of $O F$ corresponding to $\Delta Q_{\max }$ is $O F_{\triangle Q \max }$. The classes of the linked parameters are determined by comparing the values of $O F_{\text {field }} ; \Delta O F_{\Delta Q \max } ; \Delta Q_{\max }$; error in cumulative interception $(\triangle I N T)$; maximum tolerated inaccuracy of estimating cumulative interception $\left(\Delta I N T_{\max }\right)$; cumulative evapotranspiration error $\Delta E$; maximum tolerated inaccuracy of estimating cumulative evaporation $\left(\Delta E_{\max }\right)$. For this case study the maximum tolerated errors for the water fluxes is $10 \%\left(\Delta Q_{\max }=\Delta E_{\max }=\right.$ 


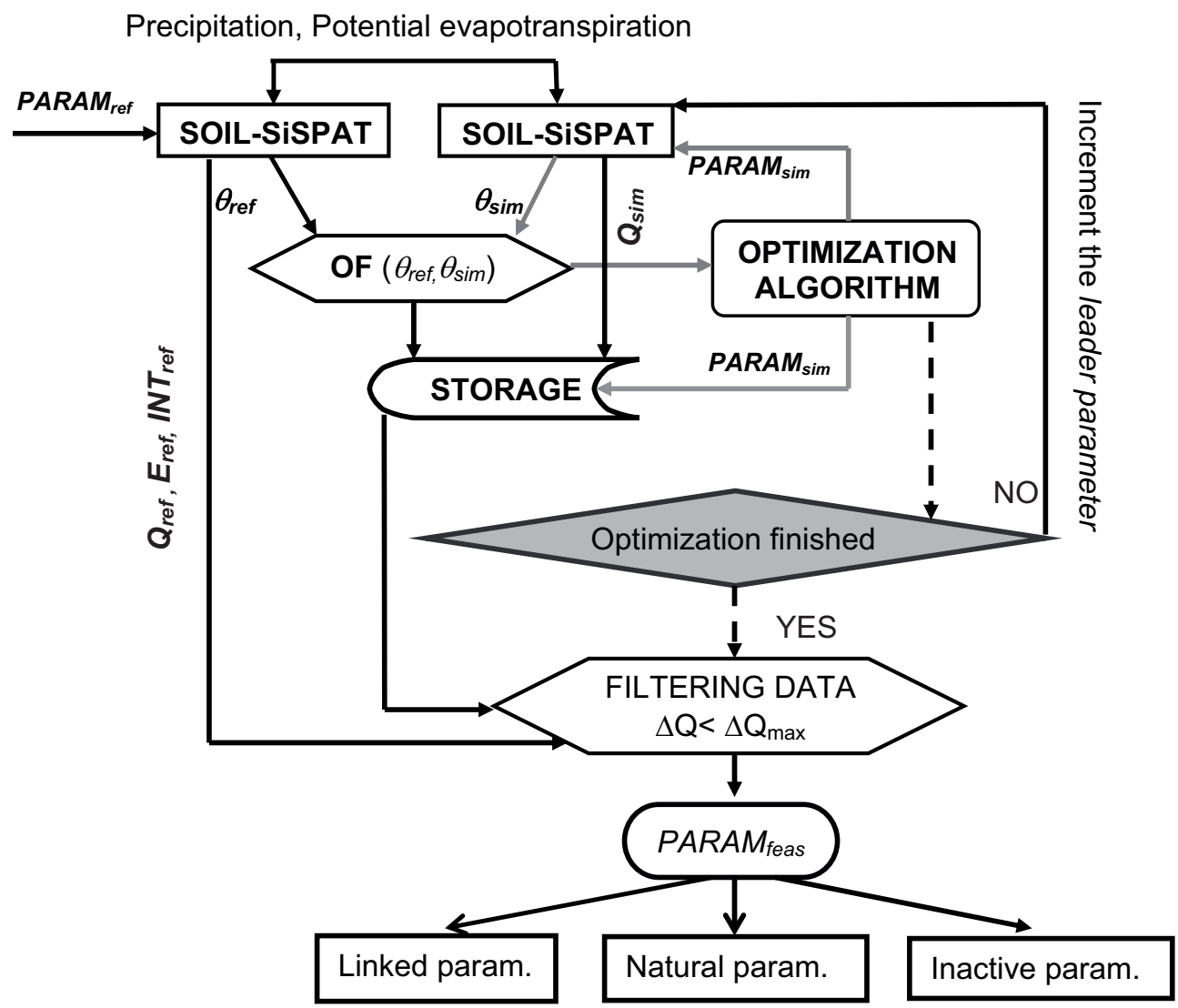

Figure 1. Flowchart describing the basis of the Linking Test. For more explanation, refer to text.

$\Delta I N T_{\max }=10 \%, \Delta E, \Delta I N T$ are determined respectively by:

$$
\begin{gathered}
\Delta E=100 \frac{\left|\sum E_{r e f}-\sum E_{\text {sim }}\right|}{\sum E_{\text {sim }}} \\
\Delta I N T=100 \frac{\left|\sum I N T_{r e f}-\sum I N T_{\text {sim }}\right|}{\sum I N T_{\text {sim }}} .
\end{gathered}
$$

The simplified flow chart of the Linking Test is presented in Figure 1. Prior to the Linking Test, the feasible parameter space must be defined. The Linking Test is simple to use and can easily be implemented in any inverse modelling problem, since it consists in running the global optimisation algorithm several times. During each optimisation run, a selected parameter is kept constant, termed by the authors "leader parameter". After each optimisation run the leader parameter is incremented in the feasible parameter space (e.g. by dividing the feasible range into 5 sections) and the remaining parameters are optimised. In our case study the crop factor $\beta(-)$ is chosen as a leader parameter. We slightly modified the global optimisation algorithm such that it stores the history of the optimisation (input/ output). When the simulation is terminated, $O F$ is plotted against $\triangle Q, \triangle I N T$, $\triangle E$ taken from the data set generated by $P A R A M_{\text {sim }}$. To determine the classes of the Linked parameter sets we use the algorithm presented in Table I that is described below.

Different scenarios can be encountered when performing an inverse modelling problem. If we are in the case for which the range of $O F<O F_{\text {field }}$ corresponds to $\Delta Q>\Delta Q_{\max }$ (Tab. I), it indicates that the selected leader parameter is not a Linking Parameter, since in order to have $\Delta Q<\Delta Q_{\max }$ the value of the leader parameter can only be
Table I. Different categories of the linked parameter sets. For further explanations refer to text. The case of $\Delta Q>\Delta Q_{\max }$ means that the

\begin{tabular}{|c|c|c|c|}
\hline \multicolumn{3}{|c|}{$Q \leq Q_{\max }$} & $Q>Q_{\max }$ \\
\hline \multirow[t]{3}{*}{$O F_{\text {field }}>O F_{\Delta Q \max }$} & \multicolumn{2}{|c|}{$O F_{\text {field }} \leq O F_{\Delta Q \max }$} & $O F_{\text {field }}>O F$ \\
\hline & $E \leq E_{\max } \mathrm{AND}$ & $E>E_{\max }$ AND & \\
\hline & $I N T \leq I N T_{\max }$ & $I N T>I N T_{\max }$ & \\
\hline $\begin{array}{c}\text { Falsely linked } \\
\text { parameters }\end{array}$ & $\begin{array}{l}\text { Truly linked } \\
\text { parameters }\end{array}$ & $\begin{array}{c}\text { Partially linked } \\
\text { parameters }\end{array}$ & $\begin{array}{c}\text { Natural } \\
\text { parameter set }\end{array}$ \\
\hline
\end{tabular}
selected leader parameter is not a Linking Parameter.

altered slightly from its optimum value (Natural parameter set). If this case is encountered, this does not guarantee that the other parameters are not Linking parameters and therefore a different leader parameter must be tested. If on the other hand we obtain $\Delta Q \leq \Delta Q_{\max }$ it means that the selected leader parameter and the other parameters that respond are sets of linking parameters. To determine the classes of the Linked parameter sets as described in the introduction we need to establish if the accuracy of the measured data $\left(O F_{\text {field }}\right)$ is adequate to get $\Delta Q \leq \Delta Q_{\max }$. If $O F_{\text {field }}>O F_{\Delta Q \max }$ then the parameters are falsely linked parameters since the measured accuracy of $\theta$ is not sufficient to get $\Delta Q \leq \Delta Q_{\max }$. In contrast if we obtain $O F_{\text {field }} \leq O F_{\Delta Q \max }$ we need to determine if the error on evapotranspiration, interception is also acceptable $\left(\Delta E \leq \Delta E_{\max }\right.$ AND $\left.\Delta I N T \leq \Delta I N T_{\max }\right)$. If this is the case, then the parameters are truly linked parameters. On the other hand if this is not the case $\left(\Delta E>\Delta E_{\max }\right.$ AND $\left.\Delta I N T>\Delta I N T_{\max }\right)$ 
Table II. Values of the reference vegetation parameters. The leafy phase starts at the beginning of May and ends at the end of October.

\begin{tabular}{|c|c|c|c|c|c|c|c|}
\hline & \multirow{2}{*}{$\begin{array}{l}\text { Transpiration } \\
\beta(-)\end{array}$} & \multicolumn{2}{|c|}{ Interception } & \multicolumn{4}{|c|}{ Root water uptake } \\
\hline & & $I N T_{\max }(\mathrm{mm} / \mathrm{day})$ & $C(-)$ & $E_{c}(-)$ & $Z_{\max }(\mathrm{m})$ & $h_{w p}(\mathrm{~cm})$ & $h_{s v}(\mathrm{~cm})$ \\
\hline Summer & 0.8 & 5.0 & 0.6 & 0.966 & 2 & -15000 & -100 \\
\hline Winter & 0.3 & 4.0 & 0.5 & 0.966 & 2 & -15000 & -100 \\
\hline Literature & \multicolumn{3}{|c|}{ (Nizinski and Saugier, 1989) } & \multicolumn{2}{|c|}{ (Jackson et al., 1996) } & \multicolumn{2}{|c|}{ (Braud et al., 2005) } \\
\hline
\end{tabular}

then only recharge (not interception or evapotranspiration) can be obtained by inverse modelling and therefore the parameters are partially linked parameters. It will be shown that the cases $\left(\Delta E \leq \Delta E_{\max }\right.$ AND $\left.\Delta I N T>\Delta I N T_{\max }\right)$ OR $\left(\Delta E>\Delta E_{\max }\right.$ AND $\left.\Delta I N T \leq \Delta I N T_{\max }\right)$ can not be encountered since an error in interception need to be balanced out with an error in evapotranspiration.

To differentiate between linked parameters and non-sensitive parameters, the Linking equation must be formulated by plotting together the different Linking parameters taken from PARAM $M_{\text {feas }}$. Thus a trend line will emerge between the Linked parameters. The nonsensitive parameters can be determined since these parameters lack sensitivity, and therefore the trend line between inactive parameters and the other Linking parameters will be more scattered.

In the case of truly or partially linked parameter sets we can compute the degree of freedom. The degree of freedom is the minimum number of parameters required by the model that is calculated by subtracting the number of optimised parameters from the number of Linking equations.

\subsubsection{Selection of the global optimisation}

The Shuffled Complex Evolution algorithm developed at the University of Arizona (SCE-UA) by Duan et al. $(1992 ; 1994)$ is selected as a global optimisation routine. SCE-UA was retained among others for many reasons. The first reason is that SCE-UA is robust and is successful in a number of complex problems (Duan et al., 1992; 1994; Kosugi 1999; Mroczkowski, 1997; Sorooshian et al., 1993). The second reason is that SCE-UA searches the global minimum by working in isolation before sharing the information. This feature is important for the Linking Test since the SCE-UA searches the best "local global optimum" in different locations of the parameter space, enabling an efficient search for the feasible parameter sets.

\subsection{Water flux model}

\subsubsection{Presentation of the model SOIL-SiSPAT}

Water flow was simulated using a modified version of the Simple Soil Plant Atmosphere Transfer model (SiSPAT) (Braud, 2000; 2002), presented in (Braud, 2005) and used by the investigators to compare various root water uptake modules. The original SiSPAT model solves 1D coupled equations for heat and water transfer within the soil, including a sink term for root equation, using the formalism proposed by Milly (1982). The prognostic variables, soil water matrix potential $h(\mathrm{~m})$ and temperature $T(\mathrm{~K})$, are derived by using an iterative solution of the finite difference method, applied to the mixed form of the water transport equation (Celia et al., 1990). In this paper, we used a simplified version, called SOIL-SiSPAT, using decoupled and isothermal equations, i.e. the mixed form of the Richards' equation (Celia et al., 1990), combined with a sink term for root extraction:

$$
\frac{\partial \theta}{\partial t}=\frac{\partial}{\partial z}\left(K(\theta)\left(\frac{\partial h}{\partial z}-1\right)\right)-S(h)
$$

$t$ is time $(\mathrm{s}) ; z$ is the vertical coordinate $(\mathrm{m})$ defined as positive downwards, $K(\theta)$ is the unsaturated hydraulic conductivity $\left(\mathrm{m} \mathrm{s}^{-1}\right)$, and $S(h)$ is the sink term describing water uptake by plant roots $\left(\mathrm{m}^{3} \mathrm{~m}^{-3} \mathrm{~s}{ }^{-1}\right)$. The details of the boundary conditions, the soil water retention and the unsaturated hydraulic conductivity are described in Appendix. The hydraulic parameters of SOIL-SiSPAT are fixed and represent a sandy soil which is representative of the study sites of Nizinski and Saugier (1989) and of Calder et al. (2002).

\subsubsection{Sink term}

To take into account tree physiology and the reduction of transpiration by soil water stress for a typical oak tree, the water uptake term is distributed over the whole root zone and is calculated for each cell (Feddes et al., 1988)

$$
s\left(h_{i}\right)=\beta E_{p} g\left(h_{i}\right) \Delta R d f_{i}
$$

where $\beta$ is the transpiration fraction (-); $E_{p}$ is the daily Penman potential evaporation estimated for short grass $\left(\mathrm{mm} \mathrm{day}^{-1}\right) ; \Delta R d f_{i}$ is the vertical fraction of the root density function per cell $i(\%) ; g\left(h_{i}\right)$ is the reduction of root water uptake at pressure head $h$ per cell $i(-)$.

\subsubsection{Transpiration fraction}

Evaporation from short grass and trees is computed by multiplying $E_{p}$ by a parameter $\beta$ (Feddes et al., 1988). The $\beta$ parameter is smaller than one and takes account of the different biophysical properties of the vegetation, which leads to a reduction in the evaporation rate $E_{p}$, even when there is no water stress. The $\beta$ parameter is somewhat analogous to the "crop factor" parameter used in the FAO method for estimating crop water requirements (FAO, 1977). The value of $\beta$ can be found in Table II.

\subsubsection{The root-density distribution}

The vertical fraction of the root density function per cell $i\left(\Delta R d f_{i}\right)$. $\Delta R d f_{i}$ defines the general shape of the roots by describing the root distribution with empirical functions. The fraction of roots per cell $i$, between $z_{\text {up }}$, the depth of the top of the cell, and $z_{\text {down }}$ the depth of the bottom of the cell can be estimated by using the power-law function of (Gale and Grigal, 1987):

$$
\Delta R d f_{i}=\frac{E_{c}^{\left|Z_{\text {down }}\right|}-E_{c}^{\mid Z \text { up } \mid}}{1-E_{c}^{\left|Z_{\max }\right|}}
$$




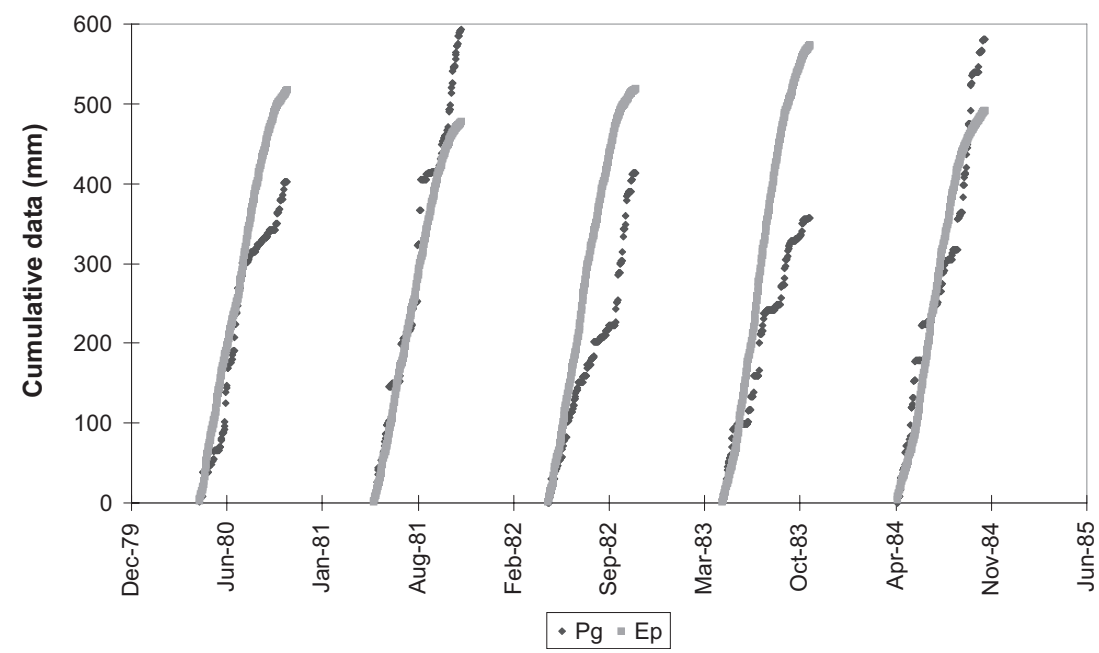

Figure 2. $P_{g}$ is the summer cumulative precipitation and $E_{p}$ is the summer cumulative potential evaporation plotted against date. Summer is taken here as the period from May to October, i.e. the leafy phase.

Table III. Average fluxes provided by the model during the leafy phase, using reference parameters and average monthly values of seasonal precipitation and Penman evaporation.

\begin{tabular}{ccccc}
\hline $\begin{array}{c}\text { Precipitation } \\
\left(\mathrm{mm} \mathrm{month}^{-1}\right)\end{array}$ & $\begin{array}{c}\text { Interception } \\
\left(\mathrm{mm} \mathrm{month}^{-1}\right)\end{array}$ & $\begin{array}{c}\text { Penman Evaporation } \\
\left.(\mathrm{mm} \mathrm{month})^{-1}\right)\end{array}$ & $\begin{array}{c}\text { Evapotranspiration } \\
\left(\mathrm{mm} \mathrm{month}^{-1}\right)\end{array}$ & $\begin{array}{c}\text { Ground water recharge } \\
\left(\mathrm{mm} \mathrm{month}^{-1}\right)\end{array}$ \\
\hline 79 & 26 & 87 & 51 & 12 \\
\hline
\end{tabular}

with $\sum_{i=1}^{i=i_{\max }} \Delta R d f_{i}=1$

$z_{u p}$ and $z_{\text {down }}$ should be positive downwards and in units of $\mathrm{cm} . E_{c}$ is the "extension coefficient" parameter, $z_{\max }$ is the root-zone depth $(L)$ and $i_{\text {max }}$ is the last cell of the root zone. The values of $E_{c}$ and $Z_{\max }$ are taken from Jackson et al. (1996) for temperate deciduous forests and are given in Table II. $E_{c}$ should be greater than 0 and smaller than 1 . When $E_{c}$ is close to 0 then all the roots are distributed in the top cell and when $E_{c}$ is close to 1 then the roots are distributed evenly within the root zone.

\subsubsection{Root water uptake}

Trees reduce their transpiration when the capillary pressure head per node $i\left(h_{i}\right)$ is smaller then $h_{S V}, h_{S V}$ being the pressure head at the onset of plant water stress, i. e. $g\left(h_{i}\right)=1$ when $h_{i}>h_{S V} \cdot g\left(h_{i}\right)=0$ when $h_{i} \leq h_{W P}, h_{W P}$ being the pressure head at wilting point. When $h_{W P}<h_{i}<h_{S V}$ then $g\left(h_{i}\right)$ reduces $E_{p}$ by the following equation (Prasad, 1986):

$$
g\left(h_{i}\right)=\frac{h_{i}-h_{W P}}{h_{S V}-h_{W P}} .
$$

The values of $h_{S V}$ and $h_{W P}$ can be found in Table II. It is assumed $h_{S V}$ that, $h_{W P}$ is constant throughout the root zone.

\subsubsection{Interception model}

Calder (1990) describes a simple empirical exponential interception model that predicts the daily loss of precipitation $\left(P_{g}\right)\left(\mathrm{cm} \mathrm{day}^{-1}\right)$ by interception (INT) $\left(\mathrm{cm} \mathrm{day}^{-1}\right)$. The simple interception model was chosen to illustrate the equifinality problem. The equation is:

$$
I N T=I N T_{\max }\left[1-\operatorname{EXP}\left(-\frac{P_{g} C}{I N T_{\max }}\right)\right]
$$

where $I N T_{\max }$ represents the maximum interception loss per day $(\mathrm{cm}$ day $^{-1}$ ) that can occur after heavy precipitation and $C(-)$ is a shape parameter $(1 \geq C>0)$ that governs the rate at which interception loss increases with increasing precipitation. Interception increases with increasing $C$ and $I N T_{\max }$. The values of $C$ and $I N T_{\max }$ are given in Table II.

\subsection{Forcing precipitation and potential evaporation}

Precipitation data used in the numerical experiments were collected at a meteorological station near the city of Fontainebleau (latitude $48^{\circ} 24 \mathrm{~N}$, longitude $2^{\circ} 42 \mathrm{E}, 50 \mathrm{~km}$ south of Paris) (Nizinski and Saugier, 1989). Solar radiation data were collected at the nearby La Miniere agricultural research station. Other inputs required to compute potential evaporation were obtained from a meteorological station at Melun (13 km from the station near Fontainebleau). The chosen period is 3 years and 7 months from 01/01/1980 to 02/08/1983. The model was run for a period of 3 months to allow the stabilisation of the outputs prior to use the data. The model runs for the whole year but the summer vegetation parameters are only calibrated during the leafy phase (May to October). The cumulative precipitation and the cumulative Penman evaporation for the summer period is shown in Figure 2. The average monthly seasonal cumulative precipitation, interception and potential evaporation are described in Table III.

\section{RESULTS OF THE LINKING TEST}

\subsection{Reference water fluxes}

To determine the reference summer fluxes $\left(Q_{r e f}, I N T_{r e f}\right.$, $\left.E_{r e f}, \theta_{\text {ref }}\right)$ for the period starting at the beginning of May and 


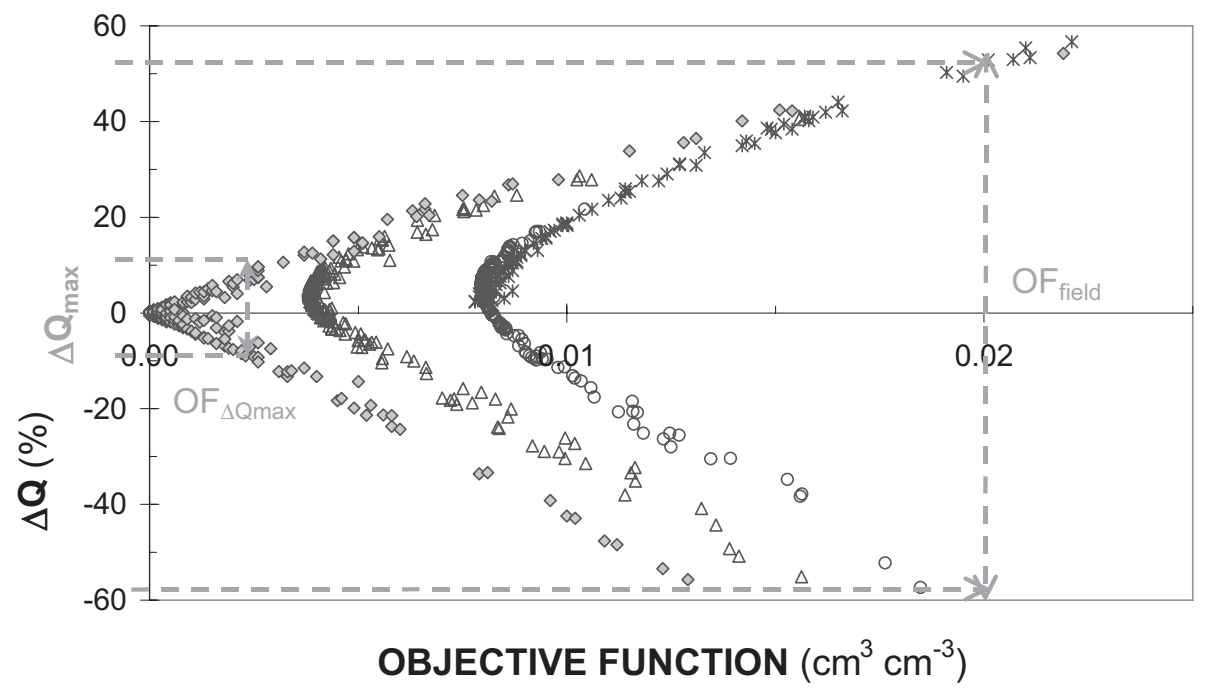

Figure 3. Relationship between Objective Function and $\Delta Q$ for different values of $\beta$.

Table IV. Range of the optimised vegetation parameters.

\begin{tabular}{lccc}
\hline & $\beta(-)$ & $I N T_{\max }(\mathrm{mm} /$ day) & $C(-)$ \\
\hline Minimum range & 0.6 & 2.0 & 0.3 \\
Maximum range & 1.0 & 10.0 & 1.0 \\
\hline Literature & & (Nizinski and Saugier, 1989) \\
\hline
\end{tabular}

ending at the end of October, SOIL-SiSPAT is run with the reference vegetation parameters $\left(P A R A M_{r e f}\right)$ described in Table II. The average monthly seasonal $Q_{r e f}, I N T_{r e f}, E_{r e f}$, are computed in Table III. The feasible range of the vegetation parameters is given in Table IV.

\subsection{Feasibility test}

To determine the feasibility of determining the vegetation parameters by inverse modelling, the OF and the correspondent $\triangle Q$ of $P A R A M_{\text {sim }}$ obtained from the Linking Test are plotted in Figure 3 for different values of $\beta$ (leader parameter). The negative values of $\Delta Q$ are regarded as positive entities. Figure 3 shows that for $\Delta Q_{\max }=10 \%$ corresponds to $O F_{\triangle Q \max } \approx 0.0025 \mathrm{~cm}^{3} \mathrm{~cm}^{-3}$ and $O F_{\text {field }}=0.02 \mathrm{~cm}^{3} \mathrm{~cm}^{-3}$. This last value is estimated by Sinclair and Williams, (1979) and by Haverkamp et al. (1984) to be the accuracy of measurement error for field experiments by using the neutron probe. Hence, $O F_{\triangle Q \max }<O F_{\text {field }}$ and therefore from Table I it is clear that the vegetation parameters are falsely linked parameters. Analysing Figure 3 shows that measuring $\theta$ with an accuracy of $O F_{\text {field }}=0.02 \mathrm{~cm}^{3} \mathrm{~cm}^{-3}$ would enable to predict recharge with a poor accuracy of $\Delta Q>58 \%$; for most hydrological studies, this accuracy is not acceptable.

The errors $\triangle I N T$ and $\Delta E$ due to measuring $\theta$ with an accuracy of $O F_{\text {field }}=0.02 \mathrm{~cm}^{3} \mathrm{~cm}^{-3}$ are of greater magnitude than $\Delta Q$. This can be appreciated in Figure 4, where a linear relationship can be seen when $\triangle I N T$ is plotted against $\triangle E$ computed from $P A R A M_{\text {feas }}$. Figure 4 shows that $\triangle I N T<70 \%$ and $\Delta E<30 \%$ even when $\Delta Q<\Delta Q_{\max }$. (The negative values of $\triangle I N T$ and $\Delta E$ are regarded in this paper as positive entities). It can be concluded that no unique vegetation parameter can be obtained by matching observed and simulated $\theta$ and the vegetation parameters are falsely linked parameters and not sets of partially linked parameters since $\Delta E>10 \%$ and $\triangle I N T>10 \%$. These finding are similar to Hupet et al. (2002; 2003), Musters et al. (2000), Musters and Bouten (1999; 2000) that found that the root water uptake parameters are not sensitive enough to be calibrated against $\theta$.

\subsection{Feasibility test to determine if $\beta$ is known, and if so, if the interception parameters can be determined by inverse modelling and vice-versa}

If $\beta$ is known [equal to 0.8 (Tab. II)] we ask if it is feasible to obtain the interception parameters by inverse modelling. Interestingly, Figure 3 shows that knowing $\beta$ does not reduce $O F_{\triangle Q \max }$ significantly, as compared to plots with $\beta \neq$ 0.8 . Thus, knowing the value of $\beta$ still does not enable of finding a unique $I N T_{\max }$ and $C$ and, therefore, the interception parameters are still falsely linked parameters.

If the interception parameters $\left(I N T_{\max }=5.0 \mathrm{~mm} \mathrm{day}^{-1}\right.$ and $C=0.6$ (Tab. II)) are known, then we ask if it is feasible to obtain $\beta$ by inverse modelling. The SOIL-SiSPAT model is run with the reference interception parameters and $\Delta Q$ is computed for different values of $\beta$ as shown in Figure 5. Figure 5 shows that $\Delta Q=15 \%$ corresponds to $O F_{\text {field }}=0.02 \mathrm{~cm}^{3}$ $\mathrm{cm}^{-3}$ that still does not meet the goal of $\Delta Q_{\max }=10 \%$ and therefore $\beta$ cannot be obtained by inverse modelling. But if $\Delta Q_{\max }=15 \%$ is considered to be acceptable by the modeller, 


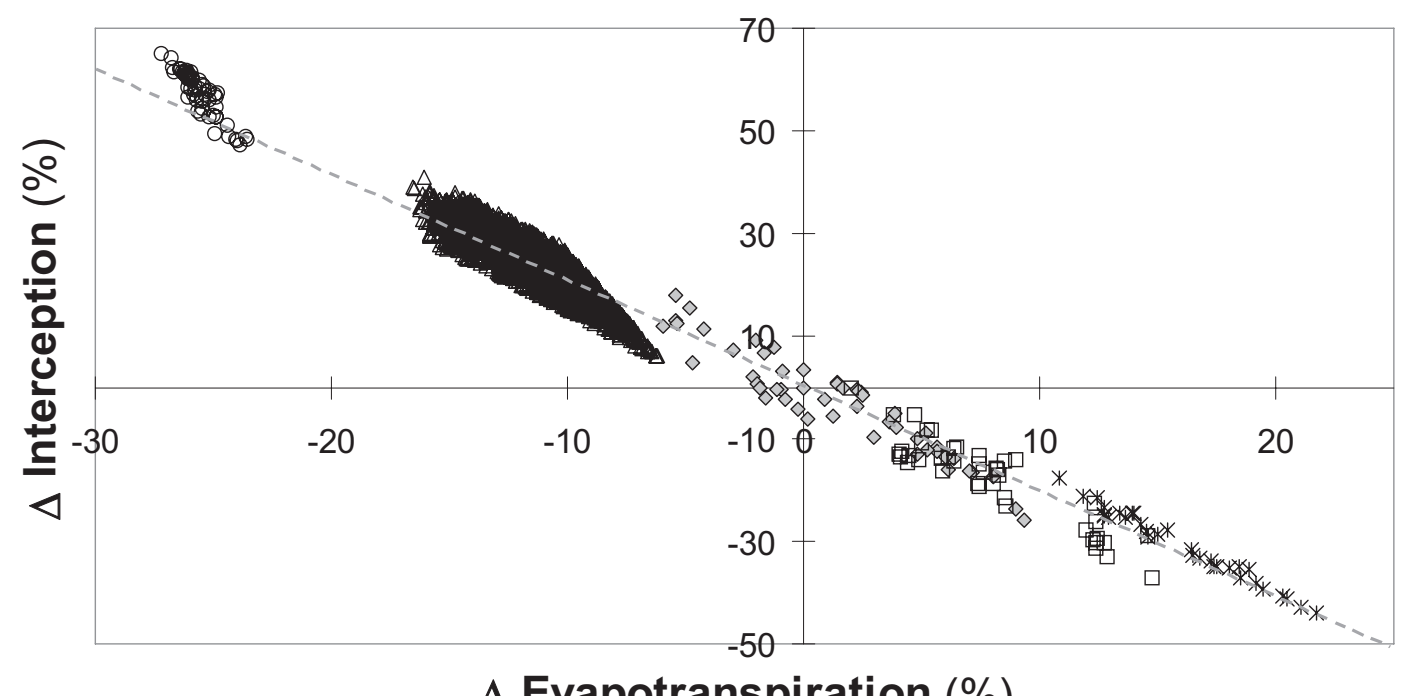

$\Delta$ Evapotranspiration (\%)

$\circ \beta=0.6 \Delta \beta=0.7 \diamond \beta=0.8 \quad \square \beta=0.9 \quad * \beta=1$

Figure 4. Relationship between evaporation and interception for different values of $\beta$ with $\Delta Q \leq 10 \%$.

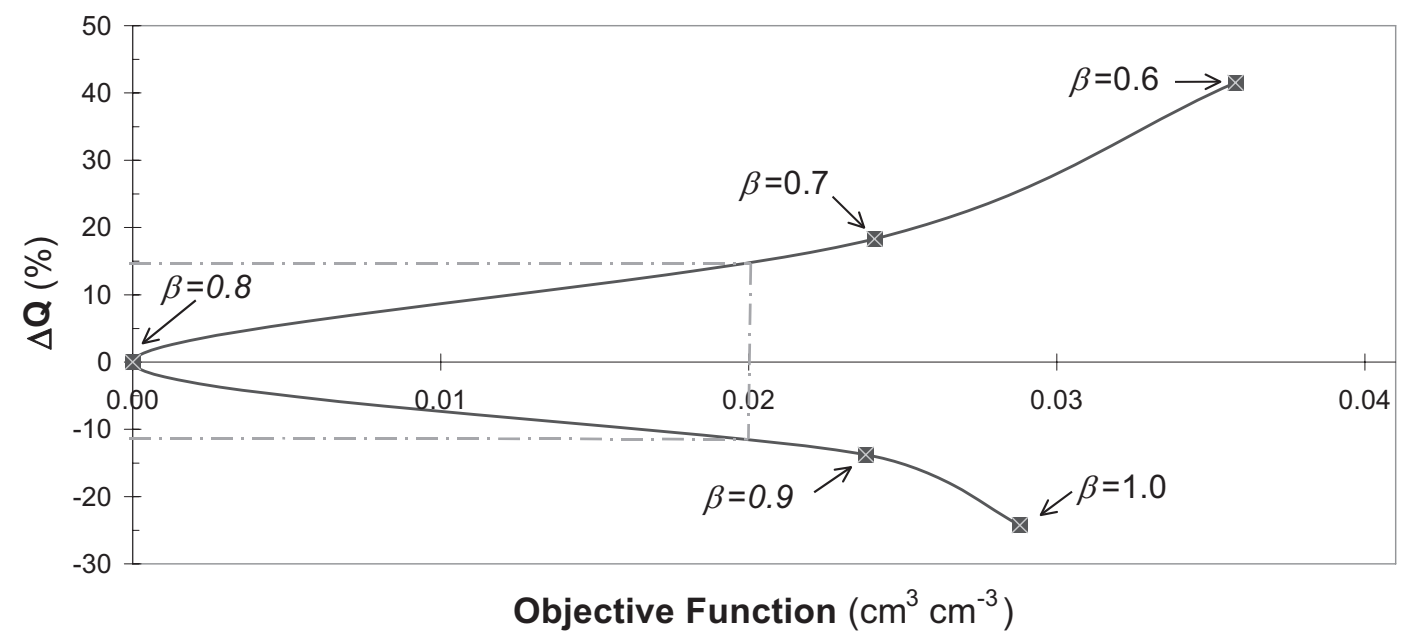

Figure 5. $\Delta Q$ is plotted against the value of the objective function for different values of $\beta . I N T_{\max }$ and $\mathrm{C}$ are reference vegetation parameters.

then $\beta$ is a natural parameter with the accuracy of estimating $\beta$ for oak with \pm 0.1 .

\section{DISCUSSION}

\subsection{Linking the vegetation parameters and the sensitive analysis}

To determine why the vegetation parameters are sets of falsely linked parameters, the linking equation derived from $P A R A M_{\text {feas }}$ is determined. The linking equation gives all the different combinations of $\beta, I N T_{\max }$ and $C$ that gives $\Delta Q \leq$ $\Delta Q_{\max }$. If $\Delta Q_{\max }$ is chosen greater than $10 \%$, the trend lines will be more dispersed. Figure 6 shows that $\beta, I N T_{\max }$ and $C$ can be linked by the following linking equation:

$$
\begin{aligned}
C= & d\left(\beta, P A R A M_{r e f}\right) I N T_{\text {max }}^{2} \\
& -e\left(\beta, P A R A M_{r e f}\right) I N T_{\max }+f\left(\beta, P A R A M_{r e f}\right)
\end{aligned}
$$

where $d, e, f$ are complex functions that depend on $\beta$ and Pollacco et al. (2008) determined that they depend strongly on the reference parameters such as the hydraulic parameters. The linking equation is considered to be true since the Linking parameters covers the whole range of the feasible parameter space given in Table IV. This plot enables to determine that $\beta, I N T_{\max }$ and $C$ are sensitive parameters since a strong relationship can be determined between these parameters. This 


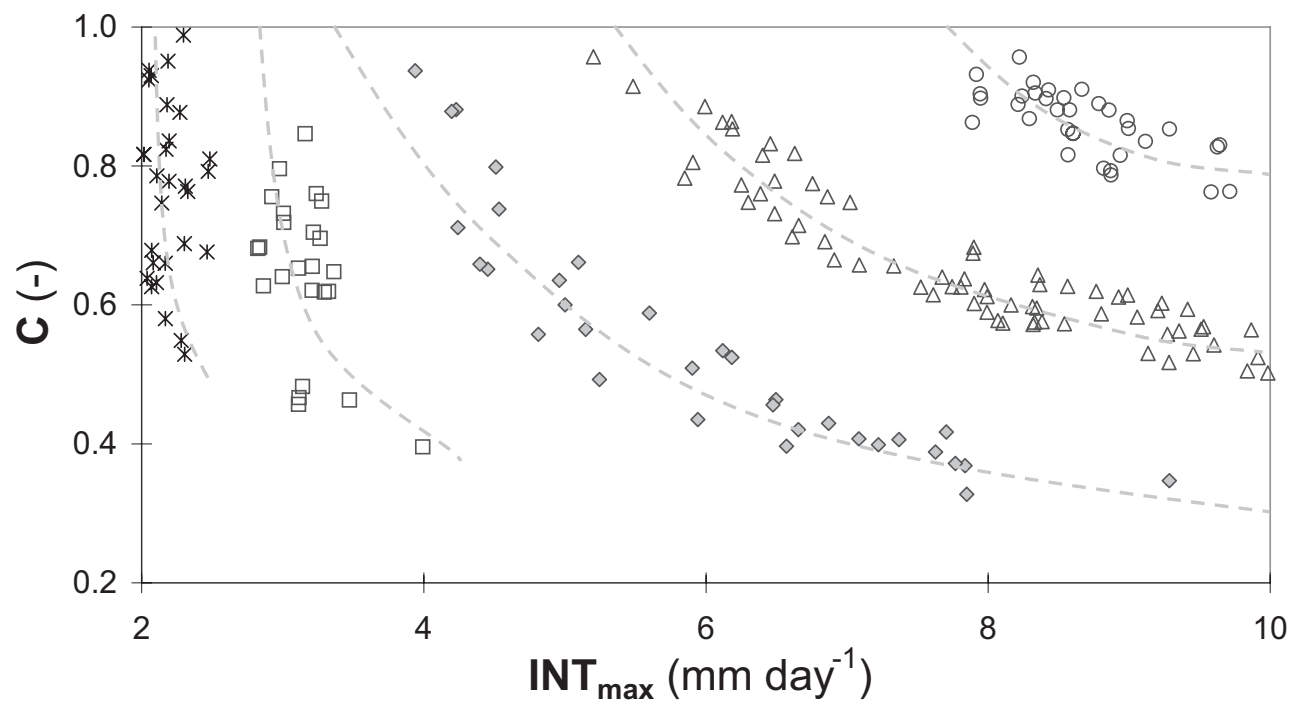

$\circ \beta=0.6 \Delta \beta=0.7 \diamond \beta=0.8 \square \beta=0.9 * \beta=1$

Figure 6. The Linkage Test is been performed by varying $\beta$ for each optimisation. Each point represents feasible parameters. For different values of $\beta$, it is shown that $I N T_{i_{\text {tmax }}}$ and $C$ are linked.

plot shows that $C$ is the least sensitive parameter since the gradient between $C$ and $I N T_{\max }$ is the steepest especially for increasing $\beta$.

\subsubsection{Reason why interception and evapotranspiration are linked}

The reason why interception and evapotranspiration are linked by Equation (8), as depicted in Figure 4, can be explained through the water uptake function or sink term (Eq. (4)) that regulates the flow. When effective precipitation (precipitation that reaches the ground) decreases through an increase in interception, there is less water available for uptake that is regulated by the water uptake function. Therefore, evapotranspiration decreases even when $\beta$ is given. On the other hand, when effective precipitation increases, there is a decrease in interception and more water is available for uptake that is regulated by the water uptake function. The balance between interception and evapotranspiration fully occurs at the end of the root zone where the roots have extracted the total amount of water. This equifinality is classified by the authors as compensation equifinality, since when the true vegetation parameter sets are not obtained, interception compensates for over or under predicting evapotranspiration and vice-versa.

\subsubsection{Reason why the interception parameters are linked}

To determine why the Linking equation (Eq. (8)) shows that $I N T_{\max }$ is linked to $C$, gross precipitation $\left(P_{g}\right)$ is plotted against feasible interception functions (Eq. (7)) with the parameters $I N T_{\text {max }}$ and $C$ taken from $P A R A M_{\text {feas }}$. To illustrate the problem $\beta$ is known and is equal to 0.8 . Figure 7 shows that for $P_{g} \leq 15 \mathrm{~mm} \mathrm{day}^{-1}$, the feasible interception functions have similar curves but diverge for $P_{g}>15 \mathrm{~mm} \mathrm{day}^{-1}$. This phenomenon is caused by the summer frequency distribution of $P_{g}$ that is plotted in Figure 7, which shows that most daily rainfall events are around $10 \mathrm{~mm} \mathrm{day}^{-1}$ and, therefore, there are very few rainfall events greater than $15 \mathrm{~mm} \mathrm{day}^{-1}$. This explains why the feasible interception functions diverges for heavy rainfall events, but has minor impact on $\Delta Q$ and $\theta$. This type of equifinality is termed frequency distribution equifinality, since if the frequency distribution was evenly distributed then frequency distribution equifinality would be less pronounced but would still exist due to compensation equifinality.

\subsection{Explanation why the linking vegetation parameters are more sensitive to groundwater recharge than to soil moisture}

Pollacco et al. (2008) found by applying the Linking Test to the SOIL-SiSPAT model that $\theta$ and groundwater recharge are sensitive to hydraulic parameters. It is understood that $\theta$ is sensitive to the hydraulic parameters, since its value regulates the characteristic curve and the unsaturated hydraulic conductivity. Interestingly, this paper shows that this is not the case for the vegetation parameters that are more sensitive to recharge than to $\theta$. This may be explained because soil moisture is the storage of water in a soil profile and, therefore, the variation of soil moisture $(\Delta \theta)$ occurs when INPUT $\left(P_{g}-I N T\right)$ is greater than OUTPUT $(Q+E)$ or vice versa. It was shown that INT and $E$ suffer from compensation equifinality and, therefore, INT and $E$ can balance out without causing a noticeable increase or decrease of the normal variation of $\theta$. If INT and $E$ do not compensate exactly then the surplus or deficient of $\theta$ is regulated by the characteristic curve and the unsaturated hydraulic 


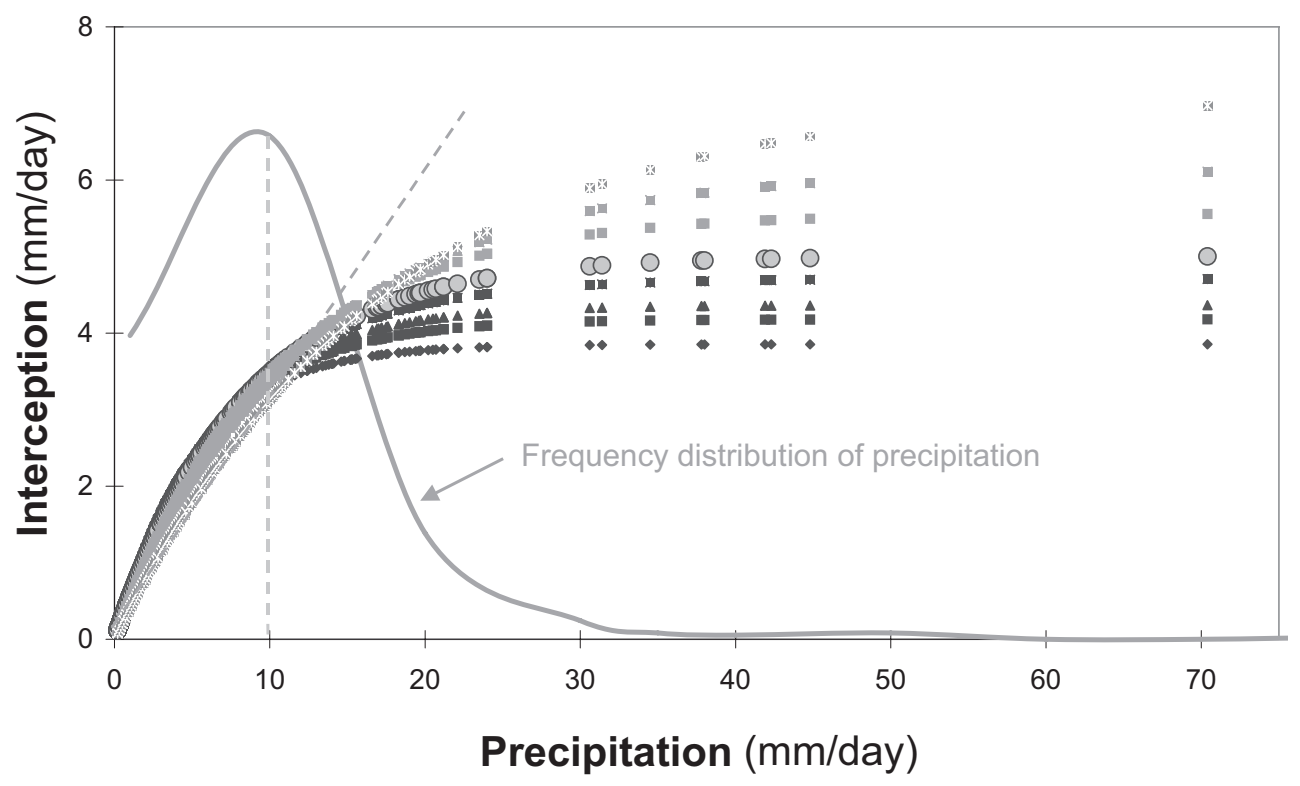

Figure 7. For $\beta=0.8$, for different feasible interception parameters described in Table IV, the interception model (Eq. (7)) is plotted against precipitation. The frequency distribution of precipitation is also given.

conductivity by increasing or decreasing $Q$ without causing a significant change of $\theta$. Therefore, $\theta$ can be seen as a conservative variable when optimising the vegetation parameters in the feasible range.

\subsubsection{Reason why $\beta$ still remains a falsely linked parameter when the interception parameters are given}

The finding than $\beta$ cannot be obtained by inverse modelling although the interception parameters are given is unexpected. Hence $\beta$ is more sensitive to recharge than to $\theta$. It is to be noted that the impact of $\beta$ directly influences the potential evaporation and indirectly the actual evapotranspiration that is regulated by the water uptake function (Eq. (4)). Therefore the sensitivity of $\beta$ would be greater when the vegetation are in the leafy phase and not under stress. Figure 5 shows that there is a good response between the errors of $\Delta \beta$ that is defined as $|\beta-0.8|$ and the error of recharge defined by $\Delta Q$. This relationship arises because by knowing interception, the effective precipitation (precipitation that reaches the ground) is known. Therefore a mass balance at the end of the root zone would indicate that $\Delta Q$ is proportional to $\Delta E$ driven by $\Delta \beta$. The reason why $\Delta \beta$ is less sensitive to $\theta$ can be understood because $\Delta E$ is distributed in the root zone with the root water uptake function (Eq. (6)) and therefore $\Delta E$ is "diluted" causing a variation of $\theta$ smaller than $O F_{\text {field }}$ for $|\Delta \beta|<0.1$.

It is therefore not recommended to determine $\beta$ by inverse modelling since the error in recharge will always be amplified compared to the accuracy of measuring soil moisture.

\section{CONCLUSION}

Inverse modelling is increasing in popularity due to the growing power of computers and the ability of estimating optimum parameter sets from limited data sets. Particularly in hydrology, emphasis is given to determine parameters in situ such as vegetation parameters, which are more representative and most often cheaper to determine than values based on laboratory or direct measurements. Nevertheless, the apparent easiness of performing inverse modelling should not overshadow that having an excellent agreement between measured and simulated data does not guarantee that the inverse modelling is feasible. This means that the optimum vegetation parameter sets and corresponding values of recharge, interception and evapotranspiration may not be unique. We applied and improved the Linking Test developed by Pollacco et al. (2008) that is able to differentiate between non-sensitive and linked parameters. The Linking Test investigates whether the inverse modelling is feasible, by establishing whether the expected accuracy of the model can be attained, which depends on the accuracy of the calibrated data. If the Linking Test establishes that the inverse modelling is unfeasible then it offers methods of exploring the causes, and ascertains if further data can alleviate the non-uniqueness.

The Linking Test is applied to a one-dimensional Richards' soil water flow model, to determine the feasibility, as claimed by Calder et al. (2002), of obtaining an optimum true interception and crop factor parameters by solely matching observed with simulated time series of soil moisture profiles. It is assumed in this case study that the hydraulic and the other vegetation parameters are known. The Linking Test established that when soil moisture data are measured with an accuracy of $0.02 \mathrm{~cm}^{3} \mathrm{~cm}^{-3}$ and when the required accuracy of determining 
groundwater recharge, interception and evapotranspiration is $10 \%$, then non-unique water fluxes may be obtained, although the fit between observed and simulated soil moisture data may be excellent. Hence, the vegetation parameters suffer from sets of falsely linked parameters. The Linking Test also showed that knowing the interception or the crop factor parameters would still not allow to alleviate the non-uniqueness problem.

The reason for non-uniqueness is that the interception and the evapotranspiration parameters are linearly linked, and therefore interception compensates for over/under predicting evapotranspiration, and vice-versa. If the water balance between interception and evapotranspiration is insufficient, then groundwater recharge will compensate without affecting soil moisture. This case is termed compensation equifinality. The other reason why the interception parameters are linked between them is due to the frequency distribution equifinality, that is caused because there are more rainfall events with small precipitation $\left(<15 \mathrm{~mm} \mathrm{day}^{-1}\right)$, than with larger precipitation. The finding than $\beta$ cannot be obtained by inverse modelling although the interception parameters are given is surprising. It is due to the fact that the error caused in evaporation is distributed in the root zone.

In this study, it is recommended that, contrary to the finding of Calder et al. (2002), the vegetation parameters should not be optimised only against soil moisture data since the outputs (recharge, evaporation, interception) are extremely sensitive to minor variations of the calibrated data (soil moisture).

Acknowledgements: This study was supported, in part, by the Laboratoire d'Écologie, Systématique et Évolution (UMR 8079 of CNRS) of the University of Paris Sud, Orsay and the Laboratoire d'Étude des Transferts en Hydrologie et Environnement (LTHE) of the University of Grenoble. The authors would like to show gratitude to Dr Georges Nizinski that generously gave us the forcing data that he collected during his Ph.D. We would like to show appreciation to Prof. Q.Y. Duan at the University of Arizona for untrusting us the code for the Shuffled Complex Evolution algorithm. We would also like to thank Lee Lihui, spouse of the first author, for her valuable assistance in designing figures and formatting the manuscript.

\section{REFERENCES}

Ball J. and Trudgill S.T., 1995. Review of solute modelling. Solute modelling in catchment systems. ST Trudgill. Overview of solute modeling. in: Solute modeling in catchement systems. Wiley, London.

Beven K.J., 1993. Prophecy, reality and uncertainty in distributed hydrological modelling. Adv. Water Resour. Res. 16: 41-51.

Bobay V., 1990. Influence d'une eclaircie sur le flux de seve et la transpiration de taillis de chataignier. Ph.D. University de Paris sud.

Bouraoui F., 2007. Testing the PEARL model in the Netherlands and Sweden, Environ. Modell. Software 22: 937-950.

Braud I., 2000. SiSPAT User's Manual Version 3.0, Laboratoire d'Étude des Transferts en Hydrologie et Environnement, Grenoble, France, $106 \mathrm{p}$.

Braud I., 2002. SiSPAT User's Manual Update, Laboratoire d'Étude des Transferts en Hydrologie et Environnement, Genoble, France,13 p.

Braud I., Dantas-Antonino A.C., Vauclin M., Thony J.L., and Ruelle P., 1995. A Simple Soil Plant Atmosphere Transfer model (SiSPAT). Development and field verification. J. Hydrol. 166: 213-250.
Braud I., Varado N., and Olioso A., 2005. Comparison of root water uptake modules using either the surface energy balance or potential transpiration. J. Hydrol. 301: 267-286.

Burdine N.T., 1953. Relative permeability calculations for pore size distribution data. Trans. Am. Inst. Univ. Metall. Pet. Eng., 198, 71-87.

Calder I.R., 1990. Evaporation in the uplands. Chichester; New York: John Wiley \& Sons.

Calder I.R., Reid I., Nisbit T., Robinson M., and Walker D.R., 2002. Trees and Drought Project on Lowland England (TADPOLE). Scoping Study Report to Department of the Environment.

Celia M.A., Bouloutas E.T., and Zarba R.L. 1990. A general massconservation numerical solution for the unsaturated flow equation. Water Resour. Res. 26: 1483-1496.

Doorenbos J. and Pruitt W.O. 1977. Guidelines for predicting crop water requirements. FAO Irrigation and Drainage Paper 24 (Rev.) Rome, $156 \mathrm{p}$.

Duan Q.Y., Sorooshian S., and Gupta V.K., 1994. Optimal use of the SCEUA global optimization method for calibrating watershed models. J. Hydrol. 158: 265-284.

Duan Q.Y., Gupta V.K., and Sorooshian S. 1992. Effective and efficient global optimisation for conceptual rainfall-runoff models. Water Resour. Res. 28: 1015-1031.

EEC 1992. Council Regulation No. 3508/92.

Cubera E. and Moreno G. 2007. Effect of single Quercus ilex trees upon spatial and seasonal changes in soil water content in dehesas of central western Spain Ann. For. Sci. 64: 3355-3364.

Ewen J., Parkin G., and O'Connell P.E., 2000. SHETRAN: a coupled surface/subsurface modelling system for 3D water flow and sediment and solute transport in river basins. ASCE, J. Hydrol. Eng. 5: 250258.

FAO, 1977. Guidelines for predicting crop water requirements. J. Doorenbos, and W.O. Pruitt (Eds.), FAO Irrigation and Drainage Paper 24 (Rev.) Rome 156 p.

Feddes R. Kabat P.J.T., van Bakel J.J.B., Bronswijk, and Halbertsma J., 1988. Modelling soil water dynamics in the unsaturated zone - state of the art. J. Hydrol. 100: 69-111.

Forestry Commission, 1998. A New Focus for England's Woodlands. Forestry Commission.

Gale M.R. and Grigal D.F., 1987. Vertical root distributions of northern tree species in relation to successional status. Can. J. For. Res. 17: 829-834.

Haverkamp R. Vauclin M., and Vachaud G., 1984. Error analysis in estimating soil water content from neutron probe measurements: I. Local standpoint. Soil. Sci. 137: 78-90.

Her Majesty's Stationary Office, 1995. Rural England: a nation committed to a living countryside. Department of the Environment, The Stationery Office.

Hupet F.S., Lambot M., Javaux M., and Vanclooster M., 2002. On the identification of macroscopic root water uptake parameters from soil water content observations. Water Resour. Res. 38: 1300.

Hupet F., Lambot S., Feddes R., van Dam J.C., and Vanclooster M. 2003. Estimation of root water uptake parameters by inverse modeling with soil water content data. Water Resour. Res. 39: 1312.

Jackson R.B., Canadell J., Ehleringer J.R., Mooney H.A., Sala O.E., and Schulze E.D., 1996. A global analysis of root distributions for terrestrial biomes. Oecologia 108: 398-411.

Keese K.E., Scanlon B.R., and Reedy R.C., 2005. Assessing controls on diffuse groundwater recharge using unsaturated flow modeling Water Resour. Res. 41 W06010, doi 10.1029/2004WR003841. 
Kosugi K.,1999. General model for unsaturated hydraulic conductivity for soils with lognormal pore-size distribution. Soil Sci. Soc. Am. J. $63,270-277$.

Krysanova V., Hattermann F., and Wechsung F., 2007. Implications of complexity and uncertainty for integrated modelling and impact assessment in river basins. Environm. Model. Soft. 22: 701-709.

Milly P.C.D., 1982. Moisture and heat transport in hysteretic, inhomogeneous porous media: a matric head-based formulation and a numerical model. Water Resour. Res. 18: 498.

Mroczkowski M., Raper G.P., and Kuczera G., 1997. The quest for more powerful validation of conceptual catchment models. Water Resour. Res. 33: 2325-2336.

Mualem Y., 1976. A new model for predicting the hydraulic conductivity of unsaturated porous media. Water Resour. Res. 12: 513-522.

Musters P.A.D. and Bouten W., 1999. Assessing routing depths of an Austrian pine stand by inverse modeling soil water content maps. Water Resour. Res. 35: 3041-3048.

Musters P.A.D. and Bouten W., 2000. A method for identifying optimum strategies of measuring soil water contents for calibrating a root water uptake model. J. Hydrol. 227: 273-286.

Musters P.A.D., Bouten W., and Verstraten J.M., 2000. Potentials and limitations of modelling vertical distributions of root water uptake of an Austrian pine forest on a sandy soil. Hydrol. Processes 14: 103-115.

Nizinski J. and Saugier B., 1989. Dynamique de l'eau dans une chênaie en forêt de Fontainebleau. Ann. Sci. For. 46: 173-186.

Pollacco J.A.P., 2005. Inverse methods to determine parameters in a physically-based model of soil water balance, University of Newcastle upon Tyne, UK, Newcastle upon Tyne, February, 190 p.
Pollacco J.A.P., Soria-Ugalde J.M., Angulo-Jaramillo R., Braud I., Saugier B., 2008. A linking Test to reduce the number of hydraulic parameters necessary to simulate groundwater recharge in unsaturated soils Adv. Water Resour. 31: 355-369.

Prasad R., 1986. A linear root water uptake model. J. Hydrol. 99: 297306.

Ross P.J., 1990. Efficient numerical methods for infiltration using Richards' Equation. Water Resour. Res. 26: 279-290.

Simunek J., Huang K., and van Genuchten M.T.h., 1998. The HYDRUS code for simulating the one-dimensional movement of water, heat, and multiple solutes in variably-saturated media. Version 6.0, Research Report No. 144, US Salinity Laboratory, University of California, Riverside, California.

Sinclair D.F., and Williams J., 1979. Components of variance involved in estimation soil water content and water content change using a neutron moisture meter. Austr. J. Soil Res. 17: 237-247.

Singh V.P., 1995. Computer models of watershed hydrology. Water Resources Publications: Littleton, Colorado.

Sorooshian S., Duan Q.Y., and Gupta V.K., 1993. Calibration of rainfallrunoff models: Application of global optimization to the Sacramento soil moisture accounting model. Water Resour. Res. 29: 1185-1194.

Van Genuchten M.T., 1980. A closed-form equation for predicting the hydraulic conductivity of unsaturated soils. Soil Sci. Am. J. 44: 892898.

White A., Cannell M.G.R., and Friend A.D. 2000., The high-latitude terrestrial carbon sink: a model analysis. GCB 6 227-245.

Zhang L., and Dawes W. 1998., WAVES - An integrated energy and water balance model. CSIRO Land and Water Technical Report No. 31/98. 


\section{NOMENCLATURE}

C

$E_{c}$

$E_{p}$

$\Sigma E_{\text {ref }}$

$\Sigma E_{\text {sim }}$

$$
\text { FILE } E_{\text {sim }}
$$

$h$

$h(\theta)$

$h_{a e}$

$$
h_{s v}
$$$$
h_{p w}
$$

INT

$I N T_{\max }$

$\Sigma I N T_{\text {ref }}$

$K(\theta)$

$K_{s}$

L

m

$n$

\section{$O F$}

$O F_{\text {field }}$

$O F_{\triangle Q \max }$ shape parameter of interception model

$$
\text { actual evapotranspiration }
$$

extension parameter

potential evaporation

$$
\text { reference cumulative }
$$

evapotranspiration

simulated cumulative

evapotranspiration

$$
\text { file that records } O F, Q_{\text {sim }}
$$$$
\text { and } P A R A M_{\text {sim }} \text { during optimisation }
$$

$$
\text { reduction of root water uptake }
$$

at pressure head per cell

$$
\text { matric potential }
$$

$$
\text { soil water retention curve }
$$

$$
\text { air-entry matrix potential or bubbling }
$$

$$
\text { pressure head }
$$

matric potential at the onset of

plant water stress

$$
\text { matric potential at permanent wilting }
$$$$
\text { point }
$$

$$
\text { interception loss per day }
$$

\begin{tabular}{|c|c|}
\hline$P A R A M_{\text {feas }}$ & sets of feasible hydraulic parameters \\
\hline \multirow[t]{2}{*}{$P A R A M_{r e f}$} & sets of reference hydraulic \\
\hline & parameters \\
\hline \multirow[t]{2}{*}{$P A R A M_{i m}$} & sets of simulated hydraulic \\
\hline & parameters \\
\hline$P_{g}$ & daily gross precipitation \\
\hline $\operatorname{PTF}(s)$ & pedo-transfer functions \\
\hline \multirow[t]{2}{*}{$q_{\text {ref }}$} & daily reference groundwater \\
\hline & recharge \\
\hline \multirow[t]{2}{*}{$q_{\text {sim }}$} & daily simulated groundwater \\
\hline & recharge \\
\hline$Q_{r e f}$ & reference cumulative groundwater recharge \\
\hline$Q_{\text {sim }}$ & simulated cumulative groundwater recharge \\
\hline$z_{\text {down }}$ & depth of bottom cell \\
\hline$z_{\max }$ & root-zone depth \\
\hline$z_{u p}$ & depth of top cell \\
\hline$\Delta Q$ & discrepancy between $Q_{r e f}$ and $Q_{\text {sim }}$ \\
\hline \multirow[t]{2}{*}{$\Delta Q_{\max }$} & maximum tolerated inaccuracy \\
\hline & of the inverse modelling \\
\hline \multirow[t]{2}{*}{$\Delta I N T$} & discrepancy between $\Sigma I N T_{r e f}$ \\
\hline & and $\Sigma I N T_{\text {sim }}$ \\
\hline$\Delta E$ & discrepancy between $\Sigma E_{r e f}$ and $\Sigma E_{\text {sim }}$ \\
\hline \multirow[t]{2}{*}{$\Delta \mathrm{RDf}_{i}$} & vertical fraction of the roots \\
\hline & density function per cell \\
\hline$\beta$ & crop factor \\
\hline$\theta$ & volumetric water content \\
\hline$\theta_{e}$ & normalised volumetric water content \\
\hline \multirow[t]{2}{*}{$\theta_{r}$} & residual water content or \\
\hline & residual degree of saturation \\
\hline$\theta_{\text {ref }}$ & reference volumetric water content \\
\hline$\theta_{s}$ & saturated volumetric water content \\
\hline$\theta_{\text {sim }}$ & simulated volumetric water content \\
\hline
\end{tabular}

$\Delta E$

maximum interception loss per day

$$
\text { reference cumulative interception }
$$

$$
\text { unsaturated hydraulic conductivity }
$$

$$
\text { saturated hydraulic conductivity }
$$

$$
\text { shape factor }
$$

$$
\text { shape parameter }
$$$$
\text { pore-size distribution }
$$

$$
\begin{aligned}
& \text { objective Function } \\
& \text { uncertainty of the soil moisture data }
\end{aligned}
$$$$
\text { greatest value of OF such that } \Delta Q=\Delta Q_{\max }
$$ 


\section{Appendix: The boundary conditions}

The lower boundary condition can be prescribed as a time series of soil matrix potential, a known flux (i.e. zero flux) or a gravitational flux. We used the latter condition in the present study, and the corresponding cumulative flux is the water flux below the root zone we extensively discuss in the paper. For the upper boundary condition, the original model solves a two source (vegetation and bare soil) energy balance system, whereas the version used in this paper is based on the prescription of a potential evaporation for bare soil and a potential transpiration for vegetation. For each soil layer, root water uptake is the product of several terms: potential transpiration, root density and a water stress correcting factor (Feddes et al., 1988). In this study, the root density function and the water stress factor are customised for trees.

The Monte-Carlo simulation approach, used to assess possible over-parameterization of the vegetation properties, requires a large number of runs. Therefore, we tried to minimize them by performing a trade-off between computing time and accuracy. We performed sensitivity tests for soil layer depth and time step (Pollacco, 2005) and retained the maximum values leading to an error on the water balance of less than $0.2 \mathrm{~mm}$ per year. The final vertical discretization is [10 1010 $10101522.522 .522 .522 .522 .51510] \mathrm{cm}$, starting from the top cell. The maximum time step was chosen to be $2500 \mathrm{~s}$, but the code automatically decreases this value, if the instantaneous water balance of each cell is larger than the prescribed value. We retained a soil column depth of $2 \mathrm{~m}$, as we showed that the use of larger values did not modify the final cumulative water flow at the bottom of the column (Pollacco, 2005).

\section{Presentation of the expressions for soil water retention, unsaturated hydraulic conductivity}

The hydraulic parameters of SOIL-SiSPAT are fixed and are given in Table V. The hydraulic parameters represent a sandy soil which is representative of the study sites of Nizinski and
Table V. Hydraulic parameters of the Mualem-van Genuchten model representing a sandy soil.

\begin{tabular}{cccccc}
\hline$\theta_{s}\left(\mathrm{~m}^{3} \mathrm{~m}^{-3}\right)$ & $\theta_{r}\left(\mathrm{~m}^{3} \mathrm{~m}^{-3}\right)$ & $h_{a e}(\mathrm{~cm})$ & $n(-)$ & $K_{s}(\mathrm{~cm} /$ day $)$ & $L(-)$ \\
\hline 0.42 & 0 & 50 & 1.63 & 144 & 0.5 \\
\hline
\end{tabular}

Saugier (1989) and Calder et al. (2002). The accuracy of modelling groundwater recharge depends to a great extent on the exact knowledge of two functions, the soil water retention $h(\theta)$, and the unsaturated hydraulic conductivity, $K(\theta)$. The $h(\theta)$ relationship is accurately described by the Mualem-van Genuchten model (Van Genuchten, 1980):

$$
\theta_{e}=\frac{\theta-\theta_{r}}{\theta_{s}-\theta_{r}}=\frac{1}{\left[1+\left(\frac{h}{h_{a e}}\right)^{n}\right]^{m}}
$$

where $\theta\left(\mathrm{cm}^{3} \mathrm{~cm}^{-3}\right)$ is volumetric water content or the fraction of water-filled pore space; $h$ is the capillary pressure head $(\mathrm{cm})$; where $\theta_{e}$ denotes the normalised volumetric water content $\left(\mathrm{cm}^{3} \mathrm{~cm}^{-3}\right) ; \theta_{r}$ and $\theta_{s}$ are respectively residual and saturated water contents $\left(\mathrm{cm}^{3} \mathrm{~cm}^{-3}\right)$; with $\theta_{r}<\theta<\theta_{s}$; $h_{a e}$ is associated to the air-entry matrix potential $\left(\mathrm{cm}^{-1}\right)$; and $n(>1)$ is a shape parameter related to the pore-size distribution (-); $m$ is a shape parameter (-). The parameters $m$ and $n$ are interrelated via the expression: $m=1-k_{m} / n$, where $k_{m}$ is chosen to be equal to unity following the assumption of the hydraulic conductivity model of Mualem (1976) and 2for the Burdine model (1953).

The unsaturated hydraulic conductivity function, $K(\theta)$, is accurately described by Mualem (1976) and Mualem-van Genuchten (1980) termed as the Mualem-van Genuchten model:

$$
K(\theta)=K_{s} \theta_{e}^{L}\left[1-\left(1-\theta_{e}^{\frac{1}{m}}\right)^{m}\right]^{2}
$$

where $L$ is a shape factor (-); $K_{s}$ is the saturated hydraulic conductivity $\left(\mathrm{cm} \mathrm{day}^{-1}\right)$. 